\title{
Phytochemical analysis and antimicrobial and antioxidant activities of Henriettea succosa (Aubl.) DC. leaves
}

\author{
Izaqueu Rodrigues da Silva ${ }^{\mathrm{a}} \odot$, Bruno Anderson de Morais ${ }^{\mathrm{a}} \odot$, Maria Isabela Ferreira de Araújo ${ }^{\mathrm{b}}{ }^{\oplus}$, \\ Paula Perazzo de Souza Barbosa ${ }^{\mathrm{c}}$, Amanda Reges de Sena ${ }^{\mathrm{a}} \odot$, Tonny Cley Campos Leite ${ }^{\mathrm{a}^{*}}$
}

a Federal Institute of Education, Science and Technology of Pernambuco, Brasil

b Federal University of Pernambuco, Brasil

*Autor correspondente (tonny.leite@barreiros.ifpe.edu.br)

\section{N F O}

\section{Keyworks}

biological activity

natural products

secondary metabolites
Palavras-chaves atividade biológica metabolitos secundários produtos naturais

\begin{abstract}
A B S T R A C T
Henriettea succosa is a tree species consumed in abundance by birds, however, there is no report on its phytochemical profile and biological activity. This study performed the phytochemical screening and the antimicrobial and antioxidant potential of $H$. succosa leaves. The hexane (Hex), ethyl acetate (AcOEt) and methanol (MeOH) extracts of the leaves were evaluated for chemical composition by Thin Layer Chromatography and spectrophotometric analysis; the antimicrobial activity was determined by the Minimum Inhibitory Concentration (MIC) and Minimum Microbicide Concentration (MMC); antioxidant activity was determined using 2,2-diphenyl-1-picrylhydrazyl (DPPH) free radical scavenging, determination of the reducing power and the phosphomolybdenum complex reduction assay. The photoprotor action of the extracts was also evaluated. The results showed a higher content of phenolic compounds (444.08 $\pm 0.020 \mathrm{mg} \mathrm{EAG/g})$ and tannins $(414.37 \pm 0.16 \mathrm{mg}$ EAG/g) in the $\mathrm{MeOH}$ extract, which was effective against Staphylococcus aureus and Serratia marcescens, with MIC of $1 \mathrm{mg} / \mathrm{ml}$ and CMM of $2 \mathrm{mg} / \mathrm{ml}$. The MIC and MMC of AcOEt for Micrococcus luteus was $1 \mathrm{mg} / \mathrm{mL}$, this was also considered the minimum concentration necessary for the Hex extract to act on the $S$. aureus strain. The $\mathrm{MeOH}$ extract showed greater antioxidant activity by the DPPH $(79.09 \%)$ and reducing power $(327.2 \pm 0.00 \mathrm{mg}$ EAA/g) methods, while the AcOEt extract showed greater activity by the phosphomolybdenum method $(40.5 \%)$. However, none of the extracts showed a photoprotective effect against UV radiation. In summary, this study revealed that the leaves of $H$. succosa have secondary metabolites with bactericidal potential, in addition to antioxidant action.
\end{abstract}

\section{R E S U M O}

Análise fitoquímica e atividades antimicrobiana e antioxidante das folhas de Henriettea succosa (Aubl.) DC. Henriettea succosa é uma espécie arbórea consumida em abundância por pássaros, no entanto, não há relatos sobre seu perfil fitoquímico e atividade biológica. Este estudo realizou a triagem fitoquímica e analisou o potencial antimicrobiano e antioxidante das folhas de $H$. succosa. Os extratos hexano (Hex), acetato de etila (AcOEt) e metanólico $(\mathrm{MeOH})$ foram avaliados quanto a composição química por Cromatografia em Camada Delgada e análise espectrofotométrica; a atividade antimicrobiana foi determinada pela Concentração Inibitória Mínima (CIM) e Concentração Mínima Microbicida (CMM); a atividade antioxidante foi determinada usando-se os ensaios de sequestro do radical 2,2difenil-1-picrilhidrazil (DPPH), de determinação do poder redutor e de redução do complexo fosfomolibdênio. Foi avaliada também a ação fotoprotetora dos extratos. Os resultados mostraram maior teor de compostos fenólicos $(444,08 \pm 0,020 \mathrm{mg}$ EAG/g) e taninos $(414,37 \pm 0,16 \mathrm{mg}$ EAG/g) no extrato $\mathrm{MeOH}$, sendo este eficaz contra Staphylococcus aureus e Serratia marcescens, com CIM de $1 \mathrm{mg} / \mathrm{mL}$ e CMM de $2 \mathrm{mg} / \mathrm{mL}$. O CIM e CMM do AcOEt para Micrococcus luteus foi $1 \mathrm{mg} / \mathrm{mL}$, essa também foi considerada a concentração mínima necessária para o extrato Hex agir sobre a cepa de $S$. aureus. O extrato $\mathrm{MeOH}$ apresentou maior atividade antioxidante pelos métodos de DPPH $(79,09 \%)$ e poder redutor $(327,2 \pm 0,00 \mathrm{mg}$ EAA/g), enquanto o extrato AcOEt apresentou maior atividade por meio do método fosfomolibdênio $(40,5 \%)$. No entanto, nenhum dos extratos apresentaram efeito fotoprotetor contra radiação UV. Em suma, este estudo revelou que as folhas de $H$. succosa possuem metabólitos secundários com potencial bactericida, além de ação antioxidante. 


\section{INTRODUCTION}

Human culture has always been influenced by plant biodiversity, mainly due to the medicinal properties it provides, thus boosting the search for bioactive compounds for the synthesis of new drugs, with secondary metabolites considered to be leading molecules both in natural form and in models for medicinal chemistry (Valli et al., 2012).

In this scenario, the Melastomataceae family stands out, which has more than 4,800 species distributed in different regions of the world, predominantly in the Neotropical area. In Brazil, it is considered the sixth largest family of Angiosperms, with 68 genera and more than 1500 species, and present in the most diverse plant formations. Among its genera is Henriettea, composed of 22 species (Arantes and Monteiro, 2002).

Henriettea succosa (Aubl.) DC., popularly known as mundururu-meloso in Brazil, is a tree species that can reach 5 to $13 \mathrm{~m}$ in height. It is a fruit tree used as food for birds frugivores and predominates in the Brazilian Atlantic Forest (Baumgratz, 2015; Cazetta et al., 2019; Costa et al., 2006). Most studies found evaluated the floristic biodiversity, structure and diversity of tree species and fungal systematics (Bonilla-Mata \& AcostaVargas, 2020; Farnum, 2019; Hernández-Restrepo et al., 2020; Machado et al., 2016; Silva et al., 2021). Given absent works in the literature about the biological activities of the referred species, this research aimed to perform the phytochemical analysis and determine the antimicrobial and antioxidant effect of the $H$. succosa leaves.

\section{MATERIAL AND METHODS}

This study was conducted at the Microbiology and Bromatology Laboratories located at the Federal Institute of Pernambuco (IFPE) - Campus Barreiros, Barreiros/PE, Brazil.

\section{Plant material}

The $H$. succosa leaves were identified by the botanist M.Sc. Earl Celestino de Oliveira Chagas, and the exsiccatae deposited in the herbarium of the Environmental Institute of the State of Alagoas (IMA-AL) under number MAC 0050941.

\section{Microorganisms}

Bacteria: Staphylococcus aureus (UFPEDA 01), Micrococcus luteus (UFPEDA 06), Bacillus subtilis (UFPEDA 16), Enterococcus faecalis (UFPEDA 138), Escherichia coli (UFPEDA 224), Serratia marcescens (UFPEDA 398), Pseudomonas aeruginosa (UFPEDA 39), Mycobacterium smegmatis (UFPEDA 71). Fungi:
Candida albicans (UFPEDA 1007). All obtained from Microorganisms of the Department of Antibiotics collection of the Federal University of Pernambuco (UFPEDA).

\section{Obtaining leaf extracts from $H$. succosa}

The leaves (2000 g) of $H$. succosa were dried for four days, in an oven with controlled temperature $\left(40{ }^{\circ} \mathrm{C}\right)$ and constant renewal of air, ground, and stored in an airtight container before extraction. The extracts were obtained through exhaustive maceration with hexane (Hex), or ethyl acetate (AcOEt), or methanol $(\mathrm{MeOH})$, in the proportion of $1: 10(\mathrm{w} / \mathrm{v})$ for seven days at room temperature. Subsequently, the material was filtered and the solvent was removed from the extract under reduced pressure, using a rotary evaporator at 65 ${ }^{\circ} \mathrm{C}$.

\section{Phytochemical profile by Thin Layer Chromatography (TLC)}

Phytochemical analysis of $H$. succosa leaf extracts was performed by Thin Layer Chromatography (TLC), using silica gel plates precoated by F254 (Wagner and Bladt, 2001). In the mobile phase of the column, $5 \mathrm{mg} / \mathrm{mL}$ of hexane extracts (Hex: AcOEt - 7:3), ethyl acetate extract (Hex: AcOEt - 6:4), and methanolic extract were applied (Hex: AcOEt: $\mathrm{MeOH}$ - 2:5:3). The eluents were used to fraction the compounds present in the extracts. Standard developers were cochromatographed for each class of phytochemical constituent. The plates were observed in an ultraviolet chamber at the wavelengths of $254 \mathrm{~nm}$ and $365 \mathrm{~nm}$.

\section{Quantification of total phenolic compounds}

Total phenolics quantify in $H$. succosa leaf extracts was performed according to Silva et al. (2006), with modifications. In a test tube $0.2 \mathrm{ml}$ of the extract $(500 \mathrm{mg} / \mathrm{ml}), 0.5 \mathrm{ml}$ of $10 \%$ FolinCiocalteu reagent $(\mathrm{v} / \mathrm{v})$ and $1 \mathrm{ml}$ of sodium carbonate solution $\left(\mathrm{Na}_{2} \mathrm{CO}_{3}\right)$ were added to a $7.5 \%$ $(w / v)$. After stirring, the samples remained for 30 minutes in the dark and at room temperature. At the end of this time, $3 \mathrm{ml}$ of distilled water were added and the reading was made at $760 \mathrm{~nm}$. The standard curve was prepared with gallic acid, and the phenol content was expressed in milligrams of Gallic Acid Equivalent per gram of extract (mg GAE/g).

\section{Determination of total tannins}

This analysis was carried out according to Shad et al. (2012) method. $500 \mu \mathrm{L}$ of each $H$. succosa leaf extracts $(500 \mathrm{mg} / \mathrm{mL})$ and 2.5 of the reagent Folin-Ciocalteu $10 \%(\mathrm{v} / \mathrm{v})$ were added in a test tube. After stirring for $3 \mathrm{~min}, 2 \mathrm{~mL}$ of $20 \%$ (w/v) 
sodium carbonate $\left(\mathrm{Na}_{2} \mathrm{CO}_{3}\right)$ was added, and then, after standing for $2 \mathrm{~h}$ in the dark, the reading was made at $725 \mathrm{~nm}$. A standard curve was drawn up using tannic acid, and the tannin content was expressed in milligrams tannic acid equivalent per gram of sample (mg TAE/g).

\section{Determination of total flavonoids}

The analysis was carried out following the methodology of Barroso et al. (2011), where $1 \mathrm{ml}$ of each $H$. succosa leaf extracts $(500 \mathrm{mg} / \mathrm{ml}), 4 \mathrm{ml}$ of distilled water, and $300 \mu \mathrm{l}$ of sodium nitrite $\left(\mathrm{NaNO}_{2}\right)$ at $25 \%(\mathrm{w} / \mathrm{v})$ were added in a test tube. After standing for $5 \mathrm{~min}, 300 \mu \mathrm{L}$ of aluminum chloride $\left(\mathrm{AlCl}_{3}\right) \quad 10 \%(\mathrm{w} / \mathrm{v}), 2 \mathrm{~mL}$ of sodium hydroxide $(\mathrm{NaOH})$ at $1 \mathrm{~mol} / \mathrm{L}$, and $2,4 \mathrm{~mL}$ of distilled water were added and, then, the reading was made at $510 \mathrm{~nm}$. A standard curve was drawn up using rutin, and the flavonoid content was expressed as milligrams rutin equivalent per gram of sample (mg RE/g).

\section{Antimicrobian activity}

\section{Inoculum}

Bacterial and fungal suspensions were prepared from cultures grown on nutrient agar (NA) and Sabouraud dextrose (SDA), respectively. The bacterial strains were incubated at $35 \pm 2{ }^{\circ} \mathrm{C}$ for $24 \mathrm{~h}$, and the fungal strains at $35 \pm 2{ }^{\circ} \mathrm{C}$ for $24-48 \mathrm{~h}$. After incubation, approximately 4-5 colonies were transferred to test tubes containing $5 \mathrm{~mL}$ of sterile saline $(0.85 \% \mathrm{NaCl})$. The resulting suspensions were vortexed for 15s (Fanem Ltda, Guarulhos, SP, Brazil). The final inoculum turbidity was normalized with a suspension of barium sulfate $(0.5$ tube on the McFarland scale). The final concentration obtained was $1-5 \times 10^{8}$ colonyforming units per milliliter $(\mathrm{CFU} / \mathrm{mL})$ for bacteria, and $1-5 \times 10^{6}(\mathrm{CFU} / \mathrm{mL})$ for the fungal strain (Ostrosky et al., 2008).

\section{Determination of Minimum Inhibitory Concentration (MIC) and Minimum Microbicide Concentration (MMC)}

The MIC of $H$. succosa leaf extracts in the strains used was determined by the broth microdilution method (Ingroff et al., 2002), where $90 \mu \mathrm{L}$ of Muller Hinton Broth (MHB) were transferred to the wells of a 96-well microdilution plate with U-shaped bottom (Alamar, Diadema, SP, Brazil). Then, $90 \mu \mathrm{L}$ of the product emulsion was inoculated from the third column of the plate (A3). Serial dilutions were performed, where a $90 \mu \mathrm{L}$ aliquot was taken from the most concentrated well to the next, producing concentrations of $0.03 \mathrm{mg}$ / $\mathrm{mL}$ in the last column (A12). Por fim, $10 \mu \mathrm{L}$ das suspensões bacterianas ou fúngicas foram adicionados em cada poço. The plates were incubated at $35 \pm 2{ }^{\circ} \mathrm{C}$ for $24 \mathrm{~h}$ for bacteria, and 28 $\pm 2{ }^{\circ} \mathrm{C}$ for $48 \mathrm{~h}$ for the fungal strain. After that time, $30 \mu \mathrm{L}$ of rezasurin $(0.1 \mathrm{mg} / \mathrm{mL})$ was added for quantitative analysis of microbial growth in the wells and determination of the relative antimicrobial activity. To determine the MMC, aliquots of $5 \mu \mathrm{L}$ of the concentrations of the extracts that presented MIC were subcultured in Petri dishes containing $\mathrm{CMH}$. After $24 \mathrm{~h}$ of incubation for bacteria $\left(35 \pm 2{ }^{\circ} \mathrm{C}\right)$ and $48 \mathrm{~h}$ for the fungus $(28 \pm 2$ ${ }^{\circ} \mathrm{C}$ ), a reading was performed to evaluate the MMC based on the controls. MMC was defined as the lowest concentration of the product capable of inhibiting bacterial or fungal growth or allowing growth of less than three CFU, resulting in a $99.9 \%$ bactericidal activity. The tests for antimicrobial activity were performed in duplicate and the results expressed by the arithmetic mean of the MIC or MMC.

\section{Determination of reducing power}

The reducing power of $H$. succosa leaf extracts was determined using the method proposed by Waterman and Mole (1994). $100 \mu \mathrm{L}$ of the extracts diluted in methanol were used, with a final concentration of $0.5 \mathrm{mg} / \mathrm{mL}$. Afterward, $8.5 \mathrm{ml}$ of distilled water, $1 \mathrm{ml}$ of the $\mathrm{FeCl}_{3}$ solution $(0.1 \mathrm{M})$ were added and, after $3 \mathrm{~min}, 1 \mathrm{ml}$ of the potassium ferricyanide solution $(0.08 \mathrm{M})$ was added. After 15 min, the reading was performed at $720 \mathrm{~nm}$. A standard curve was drawn up using ascorbic acid, and the results obtained were expressed in milligram equivalent to ascorbic acid per gram of the extract (mg EAA/g).

\section{Sequestering activity of the radical 2,2- diphenyl-1-picrilhhydrazi (DPPH)}

The test to determine the ability of $H$. succosa leaf extracts to sequester the free radical DPPH (2,2-diphenyl-1-picrilhidrazi) was carried out according to Cavin et al., (1998), with modifications, where $0.1 \mathrm{ml}$ aliquot of each extract was added to $3.9 \mathrm{ml}$ of a solution of DPPH $(0.004 \%, w / v)$ and, after resting for $30 \mathrm{~min}$ in the dark, the reading was performed at $517 \mathrm{~nm}$. Ascorbic acid was used as a standard and the percentage of the sequestering activity (\% SA) of the DPPH radical was calculated using the equation:

$$
\% \mathrm{SA}=100 \mathrm{x}\left(\mathrm{Abs}_{\text {control }}-\mathrm{Abs}_{\text {sample }}\right) / \mathrm{Abs}_{\text {control }}
$$

Where: $\mathrm{Abs}_{\text {control }}$ is the absorbance of DPPH + ethanol and $\mathrm{Abs}_{\text {sample }}$ is the absorbance of radical DPPH + sample (sample or standard). The antiradical efficiency was established using linear 
regression analysis and the results were expressed through the concentration of the sample necessary to obtain half of the sequestering activity of the $\mathrm{DPPH}$ radicals \pm average standard error $\left(\mathrm{EC}_{50} \pm\right.$ A.S.E.).

\section{Reduction test for the phosphomolybdenum complex}

The antioxidant capacity of $H$. succosa leaf extracts was evaluated using the phosphomolybdenum method (Prieto et al., 1999). Briefly, $0.3 \mathrm{~mL}$ of different concentrations $(25,50$, 100 and $150 \mu \mathrm{g} / \mathrm{mL}$ ) of the extracts were combined with $3 \mathrm{~mL}$ of the reactive solution $(0.6 \mathrm{~mol} / \mathrm{L}$ sulfuric acid, $28 \mathrm{mmol} / \mathrm{L}$ sodium phosphate, and 4 $\mathrm{mmol} / \mathrm{L}$ ammonium molybdate) in test tubes, which were incubated at $95{ }^{\circ} \mathrm{C}$ for $90 \mathrm{~min}$. The absorbance of the solution was measured at $695 \mathrm{~nm}$ against a control $(0.3 \mathrm{~mL}$ of distilled water and 3 $\mathrm{mL}$ of the reagent). For calculation purposes, the rutin pattern was considered to be $100 \%$ antioxidant activity.

$\% \mathrm{AA}=\mathrm{ABS}_{\text {sample }}-\mathrm{ABS}_{\text {control }} \mathrm{x} 100 / \mathrm{ABS}_{\text {rutin }}-$ $\mathrm{ABS}_{\text {control }}$

\section{Photoprotective activity}

The evaluation of the photoprotective activity of H. succosa leaf extracts was performed in vitro according to Mansur et al. (1986). This test aims to evaluate whether the samples provide protection against UVA and UVB radiation. For that, each extract was diluted in ethanol until a concentration of $100 \mu \mathrm{g} / \mathrm{mL}$ was obtained. The absorbance reading was performed between 290 and $320 \mathrm{~nm}$. The Sun Protection Factor (SPF) was calculated using the equation:

SPF $($ spectrometry $)=\mathrm{FC} \times 290 \sum 320 \mathrm{EE}(\lambda) \times 1(\lambda)$ $\mathrm{x}$ abs $(\lambda)$

\section{Statistical analysis}

The results of the tests were subjected to Tukey test through the Sisvar statistical program at the level of $5 \%$ probability.

\section{RESULTS AND DISCUSSION}

\section{Extract yield}

The extracts yield obtained from $300 \mathrm{~g}$ of $H$. succosa leaves were: hexane - $3 \mathrm{~g}(1 \% \mathrm{w} / \mathrm{w})$; ethyl acetate - $4 \mathrm{~g}(1.5 \% \mathrm{w} / \mathrm{w})$; and methanol - $9 \mathrm{~g} \mathrm{(3 \%}$ $\mathrm{w} / \mathrm{w})$.

\section{Phytochemical profile}

The phytochemical profile of Hex, AcOEt and $\mathrm{MeOH}$ extracts from the leaves of $H$. succosa revealed the presence of different compounds (Table 1).

Table 1 - Phytochemical profile of $H$. succosa leaves

\begin{tabular}{llll}
\hline H. sucosa & Hex & AcOEt & MeOH \\
\hline Alkaloids & - & - & - \\
\hline Coumarins & + & - & + \\
\hline Flavonoids & - & + & + \\
\hline Tannins & - & + & - \\
\hline Saponins & - & - & - \\
\hline Triterpenes & + & + & - \\
\hline Steroids & + & - & - \\
\hline Anthraquinones & - & - & - \\
\hline Essencial oils & - & - &
\end{tabular}

(-): Not detected; (+): Detected; Hex: Hexane; AcOEt: Ethyl acetate; MeOH: Methanol

Hex extract showed curmarins, triterpenes and steroids, AcOEt, flavonoids, tannins and triterpenes, and in contrast, $\mathrm{MeOH}$ presented only two of the nine compounds analyzed: flavonoids and tannins.

Due to the nonpolar nature of the hexane extract, there is a trend in lipophilic compounds extraction, such as methyl esters of fatty acids, traces of triterpenes, and coumarins (Figueiredo et al., 2008). Thus, the chemical composition of the Hex extract of the leaves of $H$. succosa adds fat-soluble compounds driven by the lipophilicity of the solvent. Also, the variation in these components can be influenced by genetic and environmental factors of the plant, a condition that distinguishes the metabolites between species of the same family.

Coumarins can be found in the roots, flowers, fruits, and leaves of vegetables, and their presence may be related, among other activities, to the antimicrobial and antioxidant actions of plant 
extracts (Detsi et al., 2017), activities reported in the present study. Generally, more complex terpenes, such as triterpenes are abundant in plants and confer bioactive properties in the prevention and treatment of malignant tumors, antiinflammatory, antimicrobial, antioxidant effect, among others (Cháirez-Ranpirez et al., 2016; Isah et al., 2016).

The presence of triterpenes in plant extracts is also related to the synthesis of plant phytosterols and steroid hormones, such as plant brassinosteroids (Bishop and Koncz, 2002), a common peculiarity in the phytochemical findings of the present study, since the presence of triterpenes and steroids in the hexane extract of $H$. succosa leaves.

The flavonoids in the AcOEt and $\mathrm{MeOH}$ extracts may be responsible for the pharmacological properties of the species, including antimicrobial, anti-inflammatory, and antioxidant action (Tsuchiya, 2010). Thus, they can contribute to the possible effects of the extracts on dermatological problems.

\section{Measurement of total phenolics, tannins and flavonoids}

Table 2 shows the results of the determination of total phenolics, tannins and flavonoids from $H$. succosa leaf extracts.

Table 2 - Dosage of total phenolics, tannins and flavonoids from $H$. succosa

\begin{tabular}{ccc}
\hline \multirow{2}{*}{ Análise } & \multicolumn{2}{c}{$\boldsymbol{\mu g} / \mathbf{m l}$ - Extrato } \\
\cline { 2 - 3 }$\left(\begin{array}{cc}\text { Phenolics } \\
(\mathrm{mg} \mathrm{GAE} / \mathrm{g})\end{array}\right.$ & $255.57 \pm 0.020$ & $\mathbf{M e O H}$ \\
\hline $\begin{array}{c}\text { Tannins } \\
(\mathrm{mg} \mathrm{TAE} / \mathrm{g})\end{array}$ & $201.7 \pm 0.01$ & $444.08 \pm 0.020$ \\
\hline $\begin{array}{c}\text { Flavonoids } \\
\text { (mg RE/g) }\end{array}$ & $171.73 \pm 0.01$ & $414.37 \pm 0.16$ \\
\hline
\end{tabular}

Gallic Acid Equivalent per gram of extract (mg GAE/g); mg rutin equivalent per gram sample (mg RE/g); mg tannic acid equivalent per gram of extract (mg TAE/g).

There was a significant increase in these classes of metabolites in the $\mathrm{MeOH}$ extract, with a predominance of phenolic compounds ( $444.08 \mathrm{mg}$ EAG/g) and tannins (414.37 mg EAT/g). The hexane extract showed concentrations below the minimum required for quantification (data not shown).

Methanol is a polar solvent capable of promoting greater solubility and interaction between the molecules present in the extract (Felhi et al., 2017), a condition that may be related to the increase in the content of phenolic compounds, tannins, and flavonoids verified in this study, when compared to the AcOEt extract and the hexane.

In plants, phenolic compounds (flavonoids, simple phenols, tannins, stilbenes) are components of the electron transport chain in mitochondria and chloroplasts, in addition to being involved in oxidation-reduction processes, growth regulation, and plant development, a mechanism related to its significant increase in quantification tests (Babenko et al., 2019). Also, they are bioactive metabolites that perform antimicrobial, antioxidant, anti-tumor, anti-inflammatory, anti- aging, and chemopreventive action (Metsämuuronen and Sirén, 2019).

However, as studies with species of the family Melastomataceae are scarce, comparative analyzes related to the phytochemical profile are difficult. However, chemical investigations with the genus Miconia, from the same family, revealed the presence of flavonoids, triterpenes, steroids, phenolic acids, quinones, tannins, and lignans (Sabbag Cunha et al., 2019), similar findings, from the phytochemical point of view to those found in the present study.

\section{Antimicrobial activity}

For the antimicrobial evaluation of the $H$. succosa leaf extracts (Table 3) against the tested microorganisms, the MIC was determined, which refers to the lowest concentration of an antimicrobial that will inhibit the visible growth of a microorganism after overnight incubation. Already MMC refers to the lowest concentration of antimicrobial that will prevent the growth of an organism after subculture on to antibiotic/extractsfree media (Andrews, 2001). 
Table 3 - Determination of the MIC and MMC of the extracts of $H$. succosa in $\mathrm{mg} / \mathrm{mL}$

\begin{tabular}{|c|c|c|c|c|c|c|c|c|c|}
\hline $\begin{array}{c}\text { Extract } \\
\text { Strain/ } \\
(\mathrm{mg} / \mathrm{mL})\end{array}$ & Parameters & 01 & 06 & 16 & 138 & 39 & 224 & 398 & 1007 \\
\hline \multirow[t]{3}{*}{ Extract Hex } & MIC & 1 & 2 & 2 & 0.5 & 4 & 1 & 2 & 1 \\
\hline & MMC & 1 & 2 & 2 & 4 & 4 & 2 & 8 & 8 \\
\hline & MMC/MIC & 1 & 1 & 1 & 8 & 1 & 2 & 4 & 8 \\
\hline \multirow{3}{*}{$\begin{array}{l}\text { Extract } \\
\text { AcOEt }\end{array}$} & MIC & 0.5 & 1 & 4 & 0.5 & 4 & 2 & 0.5 & 0.5 \\
\hline & MMC & 2 & 1 & 4 & 4 & 4 & 4 & 1 & 4 \\
\hline & MMC/MIC & 4 & 1 & 1 & 8 & 1 & 2 & 2 & 8 \\
\hline \multirow[t]{3}{*}{$\begin{array}{l}\text { Extract } \\
\text { МeOH }\end{array}$} & MIC & 1 & 0.25 & 2 & 1 & 1 & 2 & 1 & 1 \\
\hline & MMC & 2 & 1 & 4 & 4 & 4 & 4 & 2 & 8 \\
\hline & MMC/MIC & 2 & 4 & 2 & 4 & 4 & 2 & 2 & 8 \\
\hline
\end{tabular}

MIC: Minimum Inhibitory Concentration, MMC: Minimum Microbicide Concentration, HEX: hexane, AcOEt: ethyl acetate, MeOH: methanol, 01: S. aureus, 06: M. luteus, 16: B. subtilis, 138: E. faecallis, 39: P. aeruginosa, 224: E. coli, 398: S. marcencens, 1007: yeast C. albicans.

The AcOEt extract at a concentration of 0.5 $\mathrm{mg} / \mathrm{mL}$ had significant bacteriostatic and fungistatic activities, inhibiting gram-positive bacteria: $S$. aureus, E. faecallis, gram-negative: $S$. marcencens, and the fungal strain $C$. albicans. In contrast, doses of $4 \mathrm{mg} / \mathrm{mL}$ of this extract were needed to inhibit the growth of $B$. subtilis and $P$. aeruginosa. The effective antimicrobial effect of the $\mathrm{MeOH}$ extract was against the $M$. luteus strain, with MIC of $0.25 \mathrm{mg} / \mathrm{mL}$ and MMC of $1 \mathrm{mg} / \mathrm{mL}$. However, the Hex extract did not demonstrate significant bactericidal and fungicidal activities against $S$. marcencens and $C$. albicans, respectively, with MMC of $8 \mathrm{mg} / \mathrm{mL}$.

According to Rios and Recio (2005), an extract can be considered promising when it is active at a concentration below $0.1 \mathrm{mg} / \mathrm{mL}$. However, the effect of the product capable of causing the eventual death of a microorganism occurs when the MIC/MMC ratio is between 1 and 2 (Hafidh et al., 2011). Therefore, the three extracts were bactericidal against most of the tested strains, however, none of the extracts showed activity against $C$. albicans. Low antifungal efficacy may be related to chemical decomposition or microbial degradation of organic compounds by target microorganisms (Rongai et al., 2017).

Gilbert et al. (2014) observed the antibacterial effect of methanolic extract from the leaves of Dissotis thollonii Cogn against strains of E. coli, a condition favored by the significant presence of polyphenols and flavonoids in species of the family Melastomataceae. Such secondary metabolites can promote rupture of membrane lipopolysaccharides contained in gram-negative bacteria such as E. coli, thus facilitating the entry of antimicrobial compounds to target sites within the cell (Zakaria et al., 2011).

In addition, bioactive products can inhibit the synthesis of essential bacterial proteins or act on cell wall receptors, and thus prevent the growth of the pathogen (Lavigne, 2009). Thus, possibly the antibacterial potential of $H$. succosa leaf extracts was amplified by the presence of triterpenes in the sample, especially in the AcOEt extract, in which there was an increase in the number of inhibited microorganisms (Saleem et al., 2010).

\section{Antioxidant activity}

The antioxidant capacity of the Hex, AcOEt, and $\mathrm{MeOH}$ extracts from the leaves of $H$. succosa was determined by the tests: 1 - Sequestering activity of the DPPH radical; 2 - Determination of the reducing power; 3 - Phosphomolybdenum complex formation method, summarized in figures 1 and 2 . 


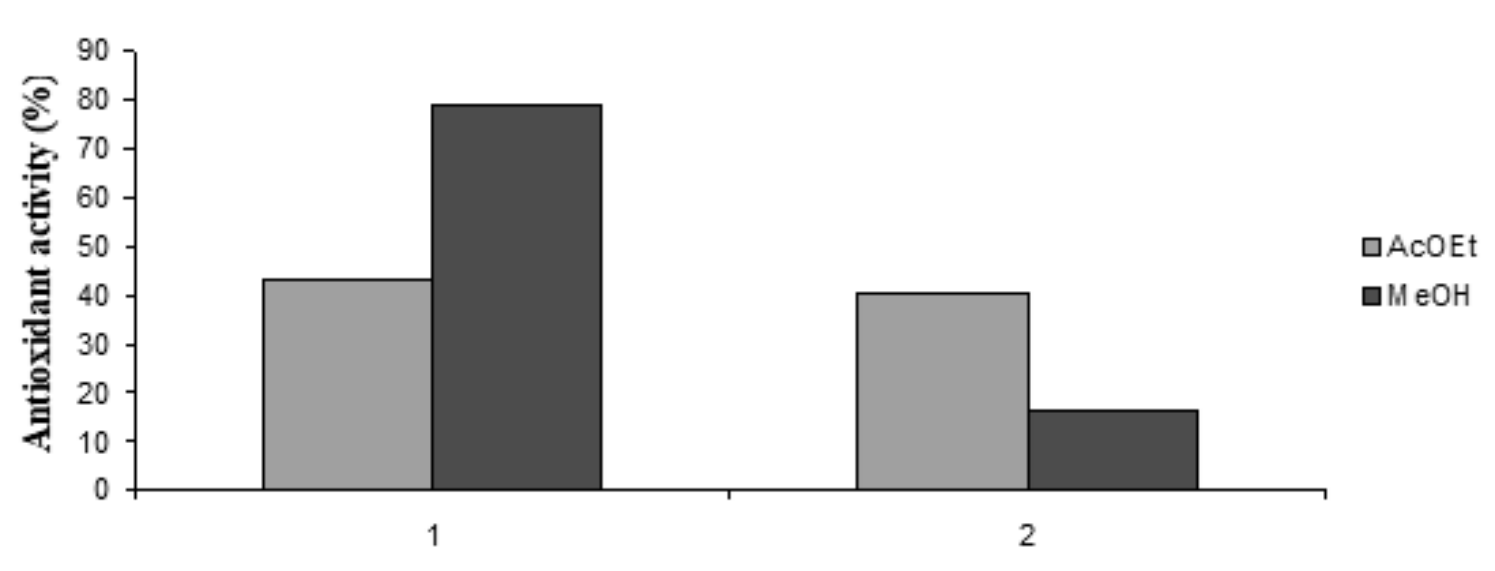

M ethods: 1 -DPPH; 2 - Phosphomolybdenum

AcOEt: Ethyl acetate; MeOH: Methanol

Figure 1 - Antioxidant activity by DPPH and Phosphomolybdenum from $H$. succosa leaves

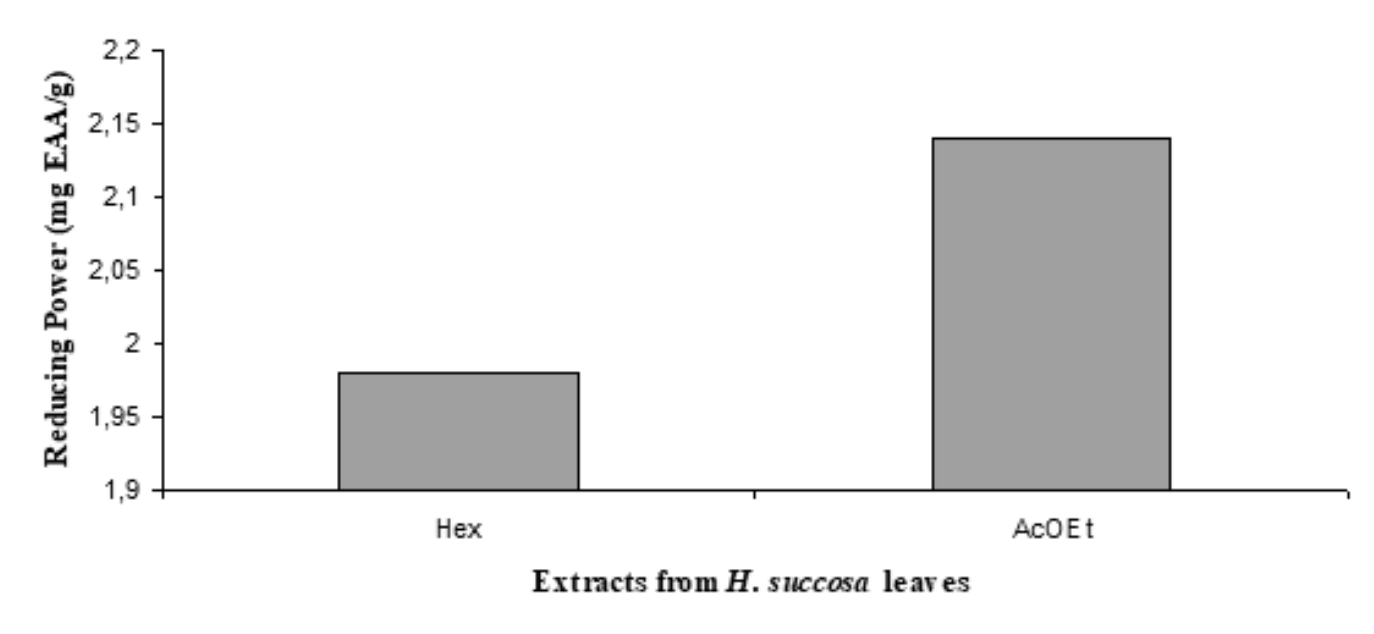

AcOEt: Ethyl acetate; $\mathrm{MeOH}$ : Methanol; mg EAA/g: milligram equivalent to ascorbic acid per gram of the sample Figure 2 - Antioxidant activity by Reducing power from $H$. succosa leaves

The free radical DPPH can be reduced in the presence of antioxidant compounds, capable of donating hydrogen atoms and, thus, making it a stable diamagnetic molecule. The $\mathrm{MeOH}$ extract exhibited a greater capacity to reduce the DPPH radical $(79.09 \pm 0.001 \%)$ when compared to the AcOEt extract $(43.53 \pm 0.050 \%)$.

The polarity of the extractive solvents contributes to the increase in the percentage of bioactive molecules, a condition related to the content of phenolic and flavonoid compounds present in the $\mathrm{MeOH}$ extract, however, the discrepancy in the water-solvent ratio can influence the solubility of the phytochemicals and thus alter the possible biological effects (Rahaiee et al., 2015), a phenomenon observed in this study, since, although the AcOEt extract contains greater varieties of metabolites when related to $\mathrm{MeOH}$ extract, it presented a low capacity for eliminating the DPPH radical.

Nzogong et al. (2018) evaluated the antioxidant capacity of two plants of the Melastomataceae family and observed low elimination of the DPPH radical by ethanolic extracts. The discrepancy in the antioxidant percentage of crude extracts from plants inserted in the same family may be related to variations in the content of antioxidant compounds, such as phenolic derivatives, therefore, the existence of such compounds could explain the antioxidant activity found in the species studied in this study.

The reducing activity of $H$. succosa leaf extracts was also carried out using the metal ion reducing potency method, a reaction that promotes the 
reduction of $\mathrm{Fe}^{+3}$ in $\mathrm{Fe}^{+2}$ by antioxidant compounds (Waterman and Mole, 1994). It was inferred that the $\mathrm{MeOH}$ extract had a greater capacity to reduce $\mathrm{Fe}^{+3}(327.2 \pm 0.00 \mathrm{mg}$ EAA/g) when compared to the AcOEt extract $(227.8 \pm 0.01 \mathrm{mg}$ EAA/g). The reducing properties of plant extracts are mostly attributed to the cleavage of the free radical and therefore the donation of hydrogen molecules, besides, they prevent the formation of peroxide precursors (Rumzhum et al., 2012).

In the phosphomolybdenum complex formation test, the phosphate/molybdenum complex is formed at acid $\mathrm{pH}$, and the subsequent reduction of molybdenum to molybdenum by the plant extract (Prieto et al., 1999). The results showed that the AcOEt extract promoted a greater reduction of molybdenum $(40.5 \pm 0.462 \%)$, an effect that may be related to the content of chemical compounds present in the extract, with synergism between them.

\section{Photoprotective activity}

The method described by Mansur is widely used to measure the sun protection factor (SPF) in vitro, its principle is to relate the absorbance of the test product with the erythematous effect of radiation and the intensity of light at wavelengths from 290 to $320 \mathrm{~nm}$ (UVB region in the spectrum) (Violante et al., 2009). Table 6 shows the SPF of Hex, AcOEt, and $\mathrm{MeOH}$ extracts from $H$. succosa leaves.

At a concentration of $100 \mu \mathrm{g} / \mathrm{mL}$, the $\mathrm{MeOH}$ extract was shown to have a higher absorbance of ultraviolet light B $(2.34 \pm 4.13)$, followed by AcOEt $(2.14 \pm 3.02)$ and Hex $(1.98 \pm 3.45)$. According to Anvisa (2012), photoprotective products must have a minimum SPF value of 6 , thus, the results obtained for the extracts used do not meet the limit required.

The increase in the protection factor of the $\mathrm{MeOH}$ extract is probably due to higher concentrations of photoprotective compounds in the sample, in general, phenolic compounds induce defense against UV radiation, since similar substances in plant species perform such functions (Rozema et al., 2001)

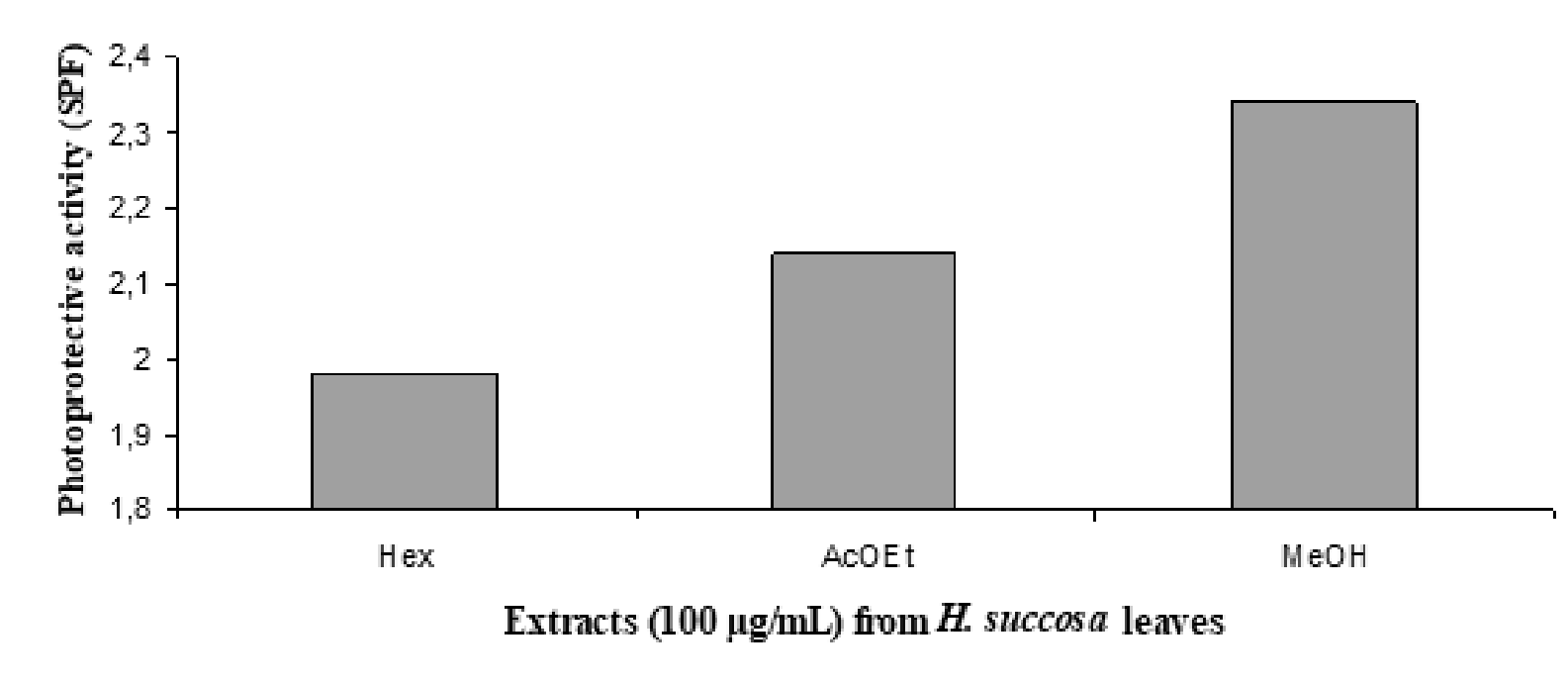

Sun Protection Factor (SPF); Hex: hexane; AcOEt: ethyl acetate; MeOH: Methanol.

Figure 3 - Photoprotective activity from $H$. succosa leaves

\section{CONCLUSIONS}

H. succosa leaf are a source of secondary metabolites, especially coumarins, flavonoids, tannins and steroids, and $\mathrm{MeOH}$ has a greater capacity to extract such compounds in significant concentrations. In addition, the tested products showed antibacterial and fungistatic activity, with emphasis on AcOEt, effective against most strains, except for S. aureus, E. faecallis and $C$. albicans. In addition, the extracts prevented and/or controlled oxidative stress, being potentially antioxidant, however, they were unable to exercise photoprotection in vitro against UV-B-induced damage. Our results are pioneering in the phytochemical and biological exploration of $H$. succosa leaves, inferring that the species has pharmacological and chemical potential for future studies, however, a more in-depth approach to the species is necessary in order to identify specific compounds and other bioactivities. 


\section{ACKNOWLEDGMENTS}

The authors would like to thank the Federal Institute of Pernambuco (IFPE) - Campus Barreiros for the structural and financial support for the implementation of this work.

\section{REFERENCES}

Andrews JM. Determination of minimum inhibitory concentrations. Journal of Antimicrobial Chemotherapy, v.48, suppl. S1, p.5-16, 2001.

Anvisa. Agência Nacional de Vigilância Sanitária (2012) Resolução $\mathrm{RDC}^{\circ}{ }^{\circ}$ 30, de 1 de junho de 2012. Avaiable in: http://www.cosmeticsonline.com.br/ct/painel/fotos/assets/uploads/regulatorios/bef6eRDC-30.pdf.

Arantes AA, Monteiro R. A família Myrtaceae na Estação Ecológica do Panga, Uberlândia, Minas Gerais, Brasil. Lundiana: International Journal of Biodiversity, v.3, n.2, p.111-127, 2002.

Babenko LM, Romanenko KO, Kosakivska IV, Smirnov OE, Trunova OK. Phenolic compounds in plants: Biogenesis and functions. The Ukrainian Biochemical Journal, v.91, n.3, p.5-18, 2019.

Barroso MF, Noronha JP, Delerue-Matos C, Oliveira MBPP. Flavored waters: influence of ingredients on antioxidant capacity and terpenoid profile by HS-SPME/GC-MS. Journal of agricultural and food chemistry, v.59, n.9, p.50625072, 2011.

Baumgratz JFA. Henriettea in Lista de Espécies da Flora do Brasil. Jardim Botânico do Rio de Janeiro. 2015. Available in: http://floradobrasil.jbrj.gov.br/jabot/floradobrasil/FB9475.

Bishop GJ, Koncz C, Brassinosteroids and plant steroid hormone signaling. The Plant Cell, v.14, n. suppl 1, p.S97S110, 2002.

Bonilla-Mata R, Acosta-Vargas LG. Dynamic and growth of the forests of the Isla del Coco National Park, Costa Rica. Revista de Biología Tropical, v.68, p.89-102, 2020.

Cavin A, Hostettmann K, Dyatmyko W, Potterat O. Antioxidant and lipophilic constituents of Tinosporacrispa. Planta medica, v.64, n.5, p.393-396, 1998.

Cazetta E, Ribeiro DAS, Cassano CR, Faria D, Dodonov P, Baumgarten JE. Forest amount, not structure, influences fruit removal of two pioneer species in Atlantic forest remnants. Biotropica, v.51, p.674-681, 2019.

Cháirez-Ramírez MH, Moreno-Jiménez MR, González-Laredo RF, Gallegos-Infante JA, Rocha-Guzmán NE. Lupane-type triterpenes and their anti-cancer activities against most common malignant tumors: A review. EXCLI journal, v.15, p.758, 2016.

Costa LCB, Rocha EA, Silva LAM, Jardim JG, Silva DC, Gaião LO, Moreira RCT. Levantamento Preliminar das Espécies Vegetais com Potencial Econômico no Parque Municipal da Boa Esperança, Ilhéus, Bahia, Brasil. Acta Farmacéutica Bonaerense, v.25, p.184-191, 2006.

Detsi A, Kontogiorgis C, Hadjipavlou-Litina D. Coumarin derivatives: an updated patent review (2015-2016). Expert opinion on therapeutic patents, v.27, n.11, p.1201-1226, 2017.
Farnum F. Caracterizacion de un bosque fragmentado em una área adyacente a La corretera boyd Roosevelt, província de Colón, Panama. Revista Colón Ciencias, Tecnología y Negócios, v.6, p.31-43, 2019.

Felhi S, Daoud A, Hajlaoui H, Mnafgui K, Gharsallah N, Kadri A. Solvent extraction effects on phytochemical constituents profiles, antioxidant and antimicrobial activities and functional group analysis of Ecballium elaterium seeds and peels fruits. Food Science and Technology, v.37, n.3, p.483-492, 2017.

Figueiredo AC, Barroso JG, Pedro LG, Scheffer JJ. Fatores que afetam a produção de metabólitos secundários em plantas: componentes voláteis e óleos essenciais.

Flavour and Fragrance Journal, v.23, p.213-26, 2008.

Gilbert A, Herve TT, William YN, Leonard SF, Jules-Roger $\mathrm{K}$, Albert K. Antidiarrhoeal and antibacterial activity of aqueous and methanolic leaves extracts of Dissotis thollonii Cogn.(Melastomataceae). Asian Pacific Journal of Tropical Biomedicine, v.4, p.S672-S678, 2014.

Hafidh RR, Abdulamir AS, Vern LS, Bakar FA, Abas F, Jahanshiri F, Sekawi Z. Inhibition of growth of highly resistant bacterial and fungal pathogens by a natural product. The open microbiology journal, v.5, p.96, 2011.

Hernández-Restrepo M, Giraldo A, Doorn RV, Wingfield MJ, Groenewald JZ, Barreto RW, Colmán AA, Mansur PSC, Crous PW. The Genera of Fungi - G6: Arthrographis, Kramasamuha, Melnikomyces, Thysanorea, and Verruconis. Westerdijk Fungal Biodiversity Institute, v.6, p.124, 2020.

Ingroff AE, Chaturvedi V, Fothergill A, Rinaldi MG. Optimal testing conditions for determining MICs and minimum fungicidal concentrations of new and established antifungal agents for uncommon molds: NCCLS collaborative study. Journal of Clinical Microbiology, v.40, n.10, p.3776-3781, 2002.

Isah MB, Ibrahim MA, Mohammed A, Aliyu AB, Masola B, Coetzer TH. A systematic review of pentacyclic triterpenes and their derivatives as chemotherapeutic agents against tropical parasitic diseases. Parasitology, v.143, n.10, p.1219-1231, 2016.

Lavigne JP. Effets des antibiotiques et mécanismes de résistance; 2009. Avaiable in: http://www.med.univmontp1.fr/enseignement/cycle_1/PCEM $/$ modbase/MB7_Bio_Med/Ressources_locales/BACTERIO/B6ATB_et_resistance.pdf.

Machado JRA, Silva NG, Duarte CC. Biodiversidade florística ameaçada pelo uso intensivo de pastagens, no município de Palmeirina - PE. Regne, v.2, p.981-990, 2016.

Mansur JDS, Breder MNR, Mansur MCDA, Azulay RD. Determinaçäo do fator de proteçäo solar por espectrofotometria. An. Bras. Dermatol, p.121-4, 1986.

Metsämuuronen S, Sirén H. Bioactive phenolic compounds, metabolism and properties: A review on valuable chemical compounds in Scots pine and Norway spruce. Phytochemistry Reviews, v.18, n.3, p.623-664, 2019.

Nzogong RT, Ndjateu FST, Ekom SE, Fosso JAM, Awouafack MD, Tene M. Antimicrobial and antioxidant activities of triterpenoid and phenolic derivatives from two Cameroonian Melastomataceae plants: Dissotis 
senegambiensis and Amphiblemma monticola. BMC complementary and alternative medicine, v.18, n.1, p.1-11, 2018.

Ostrosky EA, Mizumoto MK, Lima MEL, Kaneko TM, Nishikawa SO, Freitas BR. Métodos para avaliação da atividade antimicrobiana de determinação de concentração mínima inibitória (CMI) de plantas medicinais. Revista Brasileira de Farmacognosia, v.18, n.2, p.301-307, 2008.

Prieto P, Pineda M, Aguilar, M. Spectrophotometric quantitation of antioxidant capacity through the formation of a phosphomolybdenum complex: specific application to the determination of vitamin E. Analytical biochemistry, v. 269, n.2, p.337-341, 1999.

Rahaiee S, Moini S, Hashemi M, Shojaosadati SA. Evaluation of antioxidant activities of bioactive compounds and various extracts obtained from saffron (Crocus sativus L.): a review. Journal of Food Science and Technology, v.52, n.4, p.1881-1888, 2015.

Rios JL, Recio MC. Medicinal plants and antimicrobial activity. Journal of ethnopharmacology, v.100, n.1-2, p.80-84, 2005.

Rongai D, Pulcini P, Pesce B, Milano F. Antifungal activity of pomegranate peel extract against fusarium wilt of tomato. European Journal of Plant Pathology, v.147, n.1, p.229-238, 2017.

Rozema J, Broekman RA, Blokker P, Meijkamp BB, de Bakker N, Van de Staaij, J. UV-B absorbance and UV-B absorbing compounds (para-coumaric acid) in pollen and sporopollenin: the perspective to track historic UV-B levels. Journal of Photochemistry and Photobiology B: Biology, v.62, n.1-2, p.108-117, 2001.

Rumzhum NN, Rahman MM, Parvin MN, Chowdhury SA. Evaluation of Antioxidant, Antino Potentialities of Methanolic Extract of Memecylon umbellatum. Research Journal of Pharmacognosy and Phytochemistry, v.4, n.2, p.84, 2012.

Sabbag Cunha GO, Coelho da Cruz D, Severo Menezes AC. An Overview of Miconia genus: Chemical Constituents and Biological Activities. Pharmacognosy Reviews, v.13, n. 26,2019 .

Saleem M, Nazir M, Ali MS, Hussain H, Lee YS, Riaz N, Jabbar A. Antimicrobial natural products: an update on future antibiotic drug candidates. Natural product reports, v. 27, n. 2, p. 238-254, 2010.

Shad MA, Haq N, Tanzila R, Ahmad HB, Mazhar H. Optimization of extraction efficiency of tannins from Cichorium intybus L.: Application of response surface methodology. Journal of Medicinal Plants Research, v.6, n.28, p.44674474, 2012.

Silva TMS, Camara CA, da Silva Lins AC, Barbosa-Filho JM, da Silva EMS, Freitas BM et al. Chemical composition and free radical scavenging activity of pollen loads from stingless bee Melipona subnitida Ducke. Journal of food composition and analysis, v.19, n.6-7, p.507-511, 2006.

Tsuchiya H. Structure-dependent membrane interaction of flavonoids associated with their bioactivity. Food chemistry, v. 120, n. 4, p. 1089-1096, 2010.
Valli M, Pivatto M, Danuello A, Castro-Gamboa I, Silva DHS, Cavalheiro AJ et al. Tropical biodiversity: has it been a potential source of secondary metabolites useful for medicinal chemistry?. Química Nova, v.35, n.11, p.22782287, 2012.

Violante IM, Souza IM, Venturini CL, Ramalho AF, Santos RA, Ferrari M. Avaliação in vitro da atividade fotoprotetora de extratos vegetais do cerrado de Mato Grosso. Revista Brasileira de Farmacognosia, v.19, n.2A, p.452-457, 2009.

Wagner H, Bladt S. Plant drug analysis: a thin layer chromatography atlas. Nova York: Springer, 2001.

Waterman PG, Mole S. Analysis of phenolic plant metabolites. Blackwell Scientific Publications, 1994.

Zakaria ZA, Zakaria ML, Amom Z, Desa MN. Antimicrobial activity of the aqueous extract of selected Malaysian herbs. African Journal of Microbiology Research, v.5, n.30, p.5379-5383, 2011. 